\title{
Child in court: intersection of justice spacesand participation rights exercise ${ }^{1}$
}

\author{
CASTRO, Helga Cláudia (Portugal, Braga) ${ }^{1^{\star}}$ \\ 1 Universidade do Minho \\ ORCID ID: https://orcid.org/0000-0002-5445-6324
}

\begin{abstract}
In the Portuguese judicial system, the justice spaces were designed by adults and structured for adults, and they embrace both relational dimension and power exercise - privacy is publicized, competencies are monitored, and weaknesses are scrutinized. Research, implemented thru a multiple case study, aimed to assessment children's participation rights exercise in those same spaces. It is confirmed that childhood and children's conceptualizations have repercussions on praxis, since there is an image that associates them with lack of capacity, mirrored in and by their minority. Therefore, perpetuating children and childhood's exclusion moments, witnessing prejudice reproduction and an endemic culture of nonparticipation. Thus, child's contemporaneity must be valued, both for its presence in the breadth of human life and for the valid, and valuable contribution it makes to the composition of its living worlds.
\end{abstract}

\section{Keywords}

Space. Participation. Child. Justice. Rights.

\section{A criança em tribunal: interseção dos espaços da justiça e do exercício dos direitos de participação}

\begin{abstract}
Resumo
No sistema judicial português, os espaços da justiça foram desenhados por adultos e estruturados para os adultos e neles se vivenciam a dimensão relacional e o exercício de poder - publicita-se o privado, monitorizam-se as competências e escrutinam-se as fragilidades. A investigação, concretizada através de um estudo de caso múltiplo, teve por escopo aferir a implementação do exercício dos direitos de participação que assistem às crianças nesses mesmos espaços. Confirma-se que as conceptualizações sobre a infância e as crianças têm repercussões na práxis, uma vez que persiste uma imagem que as associa à falta de capacidade, espelhada na e pela sua menoridade. Logo, perpetuam-se momentos de exclusão das crianças e da infância, assiste-se à reprodução de preconceitos e a uma cultura de não participação endémica. Assevera-se a necessidade de valorizar a contemporaneidade da criança pela sua presença na amplitude da vida humana, como pelo contributo válido e valioso que presta na composição dos seus mundos vividos.
\end{abstract}

\section{Palavras-chave}

Espaço. Participação. Criança. Justiça. Direitos.

\footnotetext{
1 This article was presented at the III Conference on Child Studies, Universidade do
} Minho, Institute of Education.

Educação \& Formação, Fortaleza, v. 5, n. 13, p. 41-58, jan./abr. 2020 


\title{
El niño en el tribunal: intersección de los espacios
}

de justicia y lo ejercicio de derechos de participación

\begin{abstract}
Resumen
En el sistema judicial portugués los espacios de justicia fueron diseñados por adultos y estructurados para adultos y en estos se experimentan la dimensión relacional y el ejercicio del poder - se divulga lo privado, se supervisan las competencias y se examinan las debilidades. La investigación, concretizada a través de un estudio de caso múltiple, tuvo como objetivo evaluar la implementación del ejercicio de los derechos de participación de los niños en esos mismos espacios. Se confirma que las conceptualizaciones sobre la infancia y los niños tienen repercusiones en la praxis, ya que persiste una imagen que los asocia con la falta de capacidad, reflejada en y por su menor edad. Luego, resalta la existencia de momentos de exclusión de niños y de la infancia; se percibe una continuidad en la reproducción de prejuicios y una cultura de no participación endémica. Se afirma la necesidad de valorar la contemporaneidad del niño tanto por su presencia en la amplitud de la vida humana como por la contribución válida y valiosa que hace en la composición de sus mundos vividos.
\end{abstract}

Palabras clave

Espacio. Participación. Niño. Justicia. Derechos.

\section{AN OUTLINE... OF THE DIMENSION UNDER ANALYSIS}

A retrospective look on the evolution of Law and justice spaces, since the Roman age up to the 21 st century, allows us to verify that there were several prevailing models: from the Roman Forum to the medieval justice tree, churchyards, city councils, convents, Council Chambers, Palaces of Justice, and the most modern justice campus. These distinct places mirror the social, political and cultural contexts of each epoch and simultaneously evidence: how meaning has been attributed to judging's function autonomisation; how we constructed organizational and structural answers to the careers demands that gravitate towards the juridical orbit; how political context potentialized or hindered successive changes in legislation.

Family and children's jurisdiction has not been immune to these changes, especially, because in it the private is publicized and exposed, emotions and conflicts are revealed, competencies are monitored, vulnerabilities are scrutinized... Thereby, spaces create and constitute material and human relations, in addition to evidencing this underlying relational dimension. 
However, in this timeline we notice a persistent tendency that promotes separation between children's participation spaces and adults' participation spaces (GAL; DURAMY, 2015). This double and dichotomous configuration of spaces may signify:

- that children, when they have their own spaces (MANNION, 2007), value their participation times differently, as well as their communication and sharing methods and the entire decision-making process - which will be structured according to their characteristics;

- or, on the contrary, that structures and institutions concerning children in the public space "[...] often present themselves as unknown and closed structures, functioning as obstacles to children's participation spaces construction" (SARMENTO; FERNANDES; TOMÁS, 2007, p. 190, our translation), contributing to unfeasibility of children's meaningful participation.

Consequently, spaces configure one of the multiple conditions that enable children's participation rights operationalization, generally, side by side with adults in dialogical and negotiating relationships (WYNESS, 2015). Since this condition demands resources and depends on the availability of means (usually provided by government, organizations or other structures), it invariably implicates adults in the creation, organization and provision of spaces, where children will have the opportunity to express their knowledge, perspectives and/or meanings attribute to their experiences, as well as the opportunity to be heard, having their contributions considered and/or their requests granted.

Regarding Article 12 of the United Nations Convention on the Rights of the Child, which enshrines children's right to freely express their opinion on issues that concern them and have these dutifully considered, Lansdown $(2010,2011)$ clarifies that it is not dependent on a definition of age or even children's competencies, but on their ability to formulate their own perspectives, opinions and/or knowledge (whether they can be verbalized or not). In this regard, the author adds that it is necessary to: provide adequate information for children; provide safe spaces and convenient time; encourage and provide them with appropriate support to express, develop and articulate those perspectives, opinions and/or knowledge. 
Likewise, Recommendation $\mathrm{CM} / \operatorname{Rec}(2012) 2$ adopted by the Committee of Ministers on 28 March 2012 at the 1138th meeting of the Ministers' Deputies, urges member States, above all, to: support children's involvement in organizations, in community life, in intercultural education, in sports and leisure, among others; support child-oriented NGOs in order to provide spaces for learning and exercising democracy and citizenship; ensure children's representation in advisory bodies at local, regional and national levels; implement communication procedure on public services child-oriented; encourage children's participation in monitoring the United Nations Convention on the Rights of the Child and in the submission of shadow reports, as well as in the implementation of instruments of the Council of Europe and other international standards on children's rights.

The 2010 Council of Europe guidelines on child-friendly justice devote special attention to the existence of justice spaces reserved for children, stating that member States must consider child-friendly rooms, which must be available throughout the country (including rural areas) and encompass both criminal and civil proceedings. These rooms must be equipped with audio and/or video recording system and other materials that meet the needs of different age groups, in order to turn their use into common practice - because it assures their right to be heard in a free exercise, in an environment that This consideration about spaces is fundamental when usually their inexistence is acknowledged, as that of other structures that help to welcome children and listen to what they have to say. This finding is not limited to the justice dimension, as it intersects several life domains, but it is particularly relevant in distancing children from political issues (TREVISAN, 2014). However, since 2006, as shown by Carmo (2014), namely from the evaluation report on childcare, protection and guardianship systems for children and young people, there is a proposal that prescribes the existence of psychology and family hearings offices in courts, with more welcoming facilities, truly distinctive in the context of support services, rather than a bureaucraticprocedural model. 
According to the theoretical stance, adopted by childhood studies, children's participation can and should happen in the breadth of human life, because they are part of a universal sphere, cosmopolitan or global, being present in every society and in all contexts and spaces. In this regard, Qvortrup, Corsaro and Honing (2009) consider it necessary to counter the perspective that their smallness, conceptually, leads us to imprison them in a microworld or a world of particularisms, which keeps us from acknowledging that children are present: in family interactions; in foster care; in situations of family breakdown (divorce or separation); in school and kindergarten; in neighbourhood or community relationships; in commercial and consumer spaces; in civilian social organizations, youth associations, organizations created in order to promote children's participation rights, formal child representation institutions (forums, councils and/or parliaments); in political parties; among others.

Naturally, the space of excellence for participation's development begins in the private domain, that is, in family sphere and context. It is precisely in the relationship between parents and children that, as Mayall (2002) explains, there should be sharing, assuming responsibilities, dividing spaces and tasks, social and cultural involvement, among others. However, in contemporaneity, children's participation is not restricted or limited to family confinement, given increasing acknowledgement of their competencies children are today's full-fledged and complex human beings, who mirror social complexity and are much more than simple associations with innocence, a romantic ideal and a becoming.

In face of this discourse, it is crucial to articulate physical spaces and the exercise of children's participation rights in order to put into perspective their presence in court. According to concepts emerging from sociology and the problematization that has been historically conducted around relations between physical space and social life, we can list three different opinions:

[...] for some, space is essentially a social construction, tributary to social interactions and collective representations; for others, it is rather associated to a physical environment marked by selection, distribution and accommodation dynamics, which affect relationships between human beings with space and time; others yet argue, in dialectical terms, that space is the mediation of social practices imbued with contradiction. (BRANCO, 2015, p. 94, our translation). 
In order to deepen this theoretical conformation, we add that physical spaces, architecture and the very justice buildings impress on sketches and in threedimensionality the power exercise, the trait that marks and gives (in)visibility to control and domination. In this respect, we are called upon to think and debate the court as a space that is not simply an architectural building, but is equally a building that houses people and, therefore, can be identified as a space:

- that welcomes a huge diversity of recipients, among them, children;

- of social, political and legal confrontation, regulation and change;

- that shapes Law, justice and society experiences;

- full of symbolism, despite losing a distinct and pedagogical mark in the most recent organizational restructuring.

\section{DETAILED PLAN - THE OBJECTIVES}

Attending to these and other singularities, this research intended to bring into academic, public and political discussion the characterization about participation rights exercise implementation, that assist children, which is proclaimed both in the international and national current legal framework, whether in justice spaces or in court. This questioning and reflection on practices, as well as on children's rights representations, their integral development or protection needs cannot be separate, as suggested by Alcaide and Ballesté (2014), from an anchorage based in children's competencies, and not social beliefs concerning childhood, even if through a sociological analysis of law in action.

However, beyond mere positive or negative assessment of that particular right fulfilment, it was especially relevant to know and understand how children are encouraged and integrated in the decision-making process and what interactions occur in these and with these spaces in different dimensions - institution/person, formal/informal, technicality/communication, legal interpretation in a strict sense/living rights, hearing/valuing expressed knowledge, among others. Specifically considering that this challenge rewrites structures' and social actors' roles, gives visibility to policies implementation, determines new marks in children/adult's relationship and softens the hiatus between law in strict sense and law in action. 
Furthermore, understanding how to represent and construct participation's rights in judicial practice, aiding and abetting reflection and debate surrounding childhood citizenship and children's rights, as well as supporting to the continuous improvement of good practices. That is, "[...] contribute to construct new manners, new places, new spaces and new contexts that better enable to fulfil a child-friendly justice, deconstructing and overcoming terminologies and symbolic negativities" (CASTRO, 2018, p. 21, our translation).

\section{DESIGN SQUARENESS}

In front of mentioned objectives, particularly the analysis of the (in)adequacy of these spaces of and for children, is obvious an approach that crosses contributions from childhood studies and from law. Supported either on an ontological perspective marked by the exploratory, descriptive character and action analysis or by an epistemological approach with qualitative and inductive nature, seeking detailed, systematic, in-depth and contextualized understanding (BELL, 1997; DENZIN, 1998; GUBA; LINCOLN, 1994; STAKE, 2009).

In this reality representative construction, it is not careless to conceive a childhood citizenship that welcomes children as full-fledged, capable, competent human beings, therefore, active and participative subjects who are co-responsible for their life plan's decisions definition and other issues that may influence their development. Likewise, considering childhood studies presuppositions, it is asserted the overcoming of a merely legal vision and the understanding of children's rights as a work in progress, which is gradually improved with the invaluable contributions of articulation, dialogue and cooperation with and between different scientific fields (CASTRO, 2018).

This multiple case study (YIN, 2001) carried out in four different geographic scenarios - Braga, Bragança, Viana do Castelo and Vila Real counties - was chosen due to its adequacy to complexity and depth requirements, the possibility of mirroring different dimensions and contexts, as well as offering a comparison basis in the scope of the new judicial (re)organization. Therefore, the focus and methodological strategies fell upon 
articulated use of analysis techniques and methodologies, always within a qualitative paradigm (FLICK, 2005).

Concerning data collection techniques, delimited by childhood's time and the judicial procedures covered, they were applied in a natural environment, preserving their essentiality, with explicit focus on children's centrality within family and minor's judicial proceedings.

In order to carry out a broader and deeper analysis of childhood's social context, we also bring to collation the institutional and political discourses, as well as the repercussions and representation in media.

\section{OVERVIEW OF THE INTERSECTION OF JUSTICE SPACES AND CHILDREN'S PARTICIPATION EXERCISE IN JUDICIAL PROCEEDINGS}

In these four scenarios, where the exercise of children's participation rights implementation were analysed, we assess weaknesses and disparities in some spaces, namely:

- physical - either benefit from excellent conditions (Section $C^{2}$ ) or exposing unworthy conditions for the judicial function fulfilment (Section $A$ );

- symbolic - all sections (except Section D) are located in autonomous spaces, repeatedly generating difficulties for citizens concerning its identification and recognition, given the absence of symbolism and solemnity that is associated with justice architectural buildings;

- political - since the new judicial (re)organization persisted with the determination not to homogenize specialization in all counties, in Bragança family and minors' section ${ }^{3}$ still operates as local section.

Besides the lack of children's regular presence in these justice spaces, we equally confirm that the government cannot guarantee the fulfilment of this right granted to them - to be heard in a non-intimidating, non-hostile and adequate environment - given some infrastructure's conditions and lack of resources, both

${ }^{2} \mathrm{~A}, \mathrm{~B}, \mathrm{C}$ and $\mathrm{D}-$ designation attributed to different sections of family and minors that participated in the study in order to assure the lack of identification and duty of secret.

${ }^{3}$ Due to new legislation changes, nowadays, it is called family and minors court.

Educação \& Formação, Fortaleza, v. 5, n. 13, p. 41-58, jan./abr. 2020

DOI: https://doi.org/10.25053/redufor.v5i13.1940

http://seer.uece.br/redufor 
technical and human support. In Section $A$ it is ascertain that spaces allocated to secretariats are cramped, considering the number of staff and court cases; the space is not welcoming, being dark, without compelling decoration and with old furniture (which is not always in good conditions or comfortable); the summons to hearings takes place at the elevator landing, which is a cold and resonant space. In turn, Section B is located in a recently renovated building and, consequently, has different offices in order to accommodate different actors of the forum (although seldom used); aesthetically, they are sober spaces with some harmony, although equipped with "recycled" furniture from other facilities. Regarding Section C, we can verify that it offers better conditions to all who work or are directed there, since it has several rooms adequately separated according to their purposes, open, comfortable, light in colour, with good acoustics, equipped with new furniture and straight lines. Finally, Section $D$ is located on Palace of Justice second floor, has several large dimensions offices, the secretariat's space is shared with Public Prosecution, and even being an old building, it remains relatively well maintained and also has a reception and permanent security.

Regarding spaces where children's participation takes place, given aforementioned constraints, we ascertain: in Section A, children are heard in a cramped space, adjacent to Public Prosecution office; in Section B, children are heard in judges' offices or through videoconferencing; in Section $C$, children's hearings take place in judges' offices; in Section D, the existence of several spaces notwithstanding, they are sparse, seems to justify the persistent practice of hearing children in the courtroom, putting in evidence the distance (formal and symbolic) between different proceedings actors, although informality is visible in the relationship among them.

Based on court proceedings documentary analysis and on observation, in a global perspective, we notice that different professionals, such as judges, prosecutors, lawyers, multidisciplinary court support teams, children and young people protection committees, and other social security technicians: do not follow standard professional practices; are condescending and patronizing toward children's involvement in judicial proceedings, where they are, by excellence, its core; fail to recognize children as rightsholders; base some of its practices on protection's primacy, as if children were better protected through being "spared" from intervening 
and participating in their own judicial proceeding, as if their family context experience, of litigation or danger, that brought them to court, happened in a sterile, innocuous and immune glass case.

These justice spaces, therefore, reproduce prejudice and perpetuate an endemic culture of non-participation. Not being able to assure children's rights fulfilment strengths their repeated violation - whenever do not listen or listen but do not value all's children's contributions, who are an integral part of their judicial proceedings. Time, spaces and communicating methods with the child are also symptoms and symptomatic of an institutional attitude that devalues, pushes away, disregards and is not friendly or sensitive toward children.

\section{TRAITS THAT DESIGN CHILDREN'S ACKNOWLEDGEMENT AND PRESENCE IN COURT}

The scenario briefly described here translates a reality very similar to what we can observe on a global scale, as confirmed by other empirical studies (EMERSON et al., 2014). However, unlike other judicial systems, in Portugal justice spaces continue to be essentially designed by adults and structured for adults, presenting solutions that answer demands of symbology (legal, political, administrative and social) and formality, and, in this sense, exposing architectural inadequacy while spaces of and for children.

Acknowledging that children's very presence in court can be considered stressful, demanding and intimidating (RIBEIRO, 2009), either because environment and spaces are not adapted to their needs or simply because they are not sufficiently welcomed, informed and supported, when participating in civil or criminal proceedings concerning them, we restate:

- the demand that arisen, for some time now, from research (be it from psychology, forensic science, social service, law or childhood studies) which advocates welcome rooms and other specific rooms for children in every court, with didactic materials and adequate toys for different age groups; 
- in the strict fulfilment of international requirements, the creation of offices especially dedicated to children's hearings, which should encompass not only children who were victims or witnesses of abuse, but every situation that involves high parental conflict or results from the child's expressed wish to be heard in a different space;

- the allocation of spaces for supervised visit rooms especially dedicated to situations where children were removed from the family context or face exacerbated conflict situations or even that arise from children's residence definition.

In order to fulfil the task of converting children's voices into an audible and influential shout, capable of relating an event, expressing a wish, affirming a power, articulating a new language... it is crucial that they have safe spaces, adequate information, time, encouragement and support. These are, in fact, the essential requirements for children to have the opportunity of formulating, developing and articulating their own perspectives, opinions and knowledge (PERCY-SMITH; THOMAS, 2010).

Given that children's presence in court, before a judge, may occur either in the courtroom, in the judge's office or in a room prepared for that effect, according to existing conditions, spaces availability or professionals sensitivity, the United Nations Committee for Children's Rights, through the 2009 General Comment on participation, discouraged children's presence in the courtroom. Underlying this position, we find considerations about the space disposition, the established hierarchy, the centrality accentuated, the distance that is imposed, the coldness that pervades, the greatness that diminished.

In agreement with other proposals from projects and empirical studies (among others, MELO; SANI, 2015), we defend children's presence before judges in other places rather than the courtroom building or, in the rigorous fulfilment of promotion and protection model for children's rights, in specific offices and services for children, according to demands in question - victims, witnesses or defendants. Beyond these requirements, in the sense of making more child-friendly spaces, we propose the creation of playful and waiting rooms aimed at them, as well as intervention programs for their welcoming and preparation for going to court. 
Similarly, every time that other adults presence is unavoidable, it should be limited to its absolute essentiality, because, as shown by Newman, MacDougall and Baum (2009 apud FRANCISCHINI; FERNANDES, 2016), it is imperative to guarantee that children are expressing themselves freely, without constraints or restrictions on their actions and discourses.

In these conformations, it is important not to ignore that justice context is deeply conditioned (as far as this concrete research is concerned) by: guidelines of the Council of Europe about a child-friendly justice; European Commission orientations from efficiency and quality of justice report; allocation of physical, human and economic resources from government's budget; architectural building adaptation and this jurisdiction lack of priority in face of a strictly economic consideration.

In the scope of the guidelines of the Committee of Ministers of the Council of Europe (CdE, 2013), it should be emphasized, immediately, that they have origin on discrepancies acknowledgment in the practices between different nations. Therefore, it is imperative to establish rules and guidelines that promote systematic, clear and coherent supervision. In this matter, every effort must be made in order to assure more childfriendly judicial systems (encompassing before, during, and after court proceedings) and guarantee an effective and safe participation that contributes to a better functioning of the justice system:

[...] it is, in particular, justice that is accessible, age appropriate, speedy, diligent, adapted to and focused on the needs and rights of the child, respecting the rights of the child including the rights to due process, to participate in and to understand the proceedings, to respect for private and family life and to integrity and dignity. (CdE, 2013, p. 17, our translation).

Therefore, in spaces configuration, either physical or symbolic:

- all obstacles to access to justice must be removed;

- procedures must take place in a non-intimidating and child-friendly environment;

- children must be familiarized with court's configuration and also the names of all professionals involved; 
- children's hearings must include regular breaks, and must not be overly long;

- hearing and waiting rooms must be organized in order to create a proper environment for children;

- all efforts must be made for children to give their statements in a favourable environment and under the most convenient conditions according to their age, maturity, understanding levels or other communication difficulties they may have;

- children's access to courts and complaint mechanisms must be user-friendly;

- specialized and accessible support and information services must be established.

These guidelines are pioneers in the European regional context and constitute more than a simple declaration of principles; so, they are intended as an eminently practical guide for procedures implementation - before, during and after judicial decisions - "[...] ensuring that children's justice spaces must respect the privacy principle, the conflicts nature and facts on which judicial intervention is based upon, the diligences specificity" (BRANCO; CASALEIRO; PEDROSO, 2011, p. 55 apud CARMO, 2014, p. 21, our translation).

However, we may always add that the same Council of Europe guidelines on child-friendly justice can be seen as a lever to a greater extent of practices in participation rights exercise, whose scope calls for more participatory, more involved and more implicated dynamics of children themselves in the processes definition, as well as in their own evaluation (KEKI, 2013).

As it has been explained, there are several legal documents that enshrine the need to guarantee appropriate conditions for a voluntary and adequate children's hearing, provided through an room specially devoted to that procedure, that is adequate, nonhostile, detached from symbolism and power affirmations, where children have the opportunity of always meet with the same professional, who is duly qualified to engage and construct that dialogue with children, among which are: Council Regulation (EC) No 2201/2003 of 27 November 2003 (amended by Council Regulation (EC) No 2116/2004 of 2 December 2004, and corrected by Corrigendum OJ L 297/2016,4.11.2016, p. 25), Parliamentary Assembly Recommendation 1864 (2009), Committee of Ministers 
Recommendation CM/Rec(2012)2, Commission Recommendation (2013/112/EU) of 20 February 2013, among others.

Although nowadays we do not observe that new court buildings obey a unique, distinct and officially determined architectural style, as was the case up to the New State, on the contrary, we observe that justice buildings have an undifferentiated architectural logic, marked by lack of singularity and exclusivity even in the construction or adaptation of common buildings, with nothing distinguishing them from others, except for "[...] the toponymic plaque and the inscription Domus lustitia" (NUNES, 2003 apud BRANCO, 2015, p. 98-99).

Nevertheless, since Justice of Rome and Ancient Greece social centrality, until contemporaneity and its new territorialisation forms, attending the respect for human dignity, human rights and other justice principles, it is a requirement to guarantee that all courts have adequate waiting rooms, adapted toilets and a pantry/kitchen, because children's time is different from adults' time. Perhaps (re) think symbolism - the sword and blindfold - since maybe nowadays it does not have as much meaning, especially when it is argued that justice needs to BE, SEE, LISTEN, FEEL the child.

From the dialogue among different knowledge, the research results as well as formulated reflection, there is the need to reflect and debate court as a space with children inside and, therefore, it is paramount to reframe how we think about them. For that, we need to know who they are, what discourse fits better their narratives, what method they choose to express themselves, in addition to definitely assuming that spontaneity and age should not be credibility markers and that the contribution they bring into judicial decision composition is essential, because it translates a more complete view on the situation under analysis and combines a perspective of childhood citizenship that should be fulfilled.

Recognizing that different conflicts and abuses that, directly or indirectly, bring children to court scene imply an understanding of several phenomena, since context is increasingly complex, demands intervention and a multi and interdisciplinary dialogue, that cannot overlook children's centrality and alterity, as well as absolute respect for children's time. 
Another space, perhaps even more vital, is temporal space, in which celerity, adequate and assertive intervention, most up-to-date definition of their life plan is determinant for each child who tells and writes their history in court. Beyond the marks of time in each child's life and childhood, there are also the marks left by time in space, which we attempted to unveil and that deserve other looks, other perspectives, so that history does not repeat itself.

Thus, we seek to collaborate towards a new manner of recognizing children in justice space... by their presence, their word and their will's expression, so that "[...] In the end children will not only become more visible, but above all they will become visible in a different way (as meaning-makers)" (VERHELLEN, 2015, p. 55).

\section{REFERENCES}

ALCAIDE, C. V.; BALLESTÉ, I. R. How children are discriminated in the use of their rights. In: KUTSAR, D.; WARMING, H. (Ed.). Children and non-discrimination: an interdisciplinary textbook. Tallinn: University of Estonia, 2014. p. 208-220.

BELL, J. Como realizar um projecto de investigação. Lisboa: Gradiva, 1997.

BRANCO, P. Análise da arquitetura judiciária portuguesa: as dimensões de reconhecimento, funcionalidade e acesso à justiça. e-Cadernos CES, Coimbra, v. 23, p. 93-122, 2015.

CARMO, R. A nova organização do sistema judiciário e a jurisdição de família e menores. Revista do Ministério Público, Coimbra, n. 140, p. 9-32, 2014.

CASTRO, H. C. O tempo da infância no(s) tempo(s) da justiça: uma análise do exercício dos direitos de participação das crianças nos processos judiciais. 2018. $488 \mathrm{f}$. Tese (Doutoramento em Estudos da Criança) - Programa de Pós-Graduação em Estudos da Criança, Universidade do Minho, Braga, 2018.

CONSELHO DA EUROPA. Diretrizes do Comité de Ministros do Conselho da Europa sobre a justiça adaptada às crianças. Strasbourg: Council of Europe, 2013.

DENZIN, N. The art and politics of interpretation. In: DENZIN, N.; LINCOLN, Y. (Ed.). Collecting and interpreting qualitative materials. London: Sage, 1998. p. 313-344. 
EMERSON, L. et al. The legal needs of children and young people in Northern Ireland: the views of young people and adults' stakeholders. Belfast: Centre for Children's Rights, School of Education, Queen's University Belfast, 2014.

FLICK, U. Métodos qualitativos na investigação científica. Lisboa: Monitor, 2005.

FRANCISCHINI, R.; FERNANDES, N. Os desafios da pesquisa ética com crianças. Estudos de Psicologia, Campinas, v. 33, n. 1, p. 61-69, 2016.

GAL, T.; DURAMY, B. F. International perspectives and empirical findings on child participation: from social exclusion to child inclusive policies. Oxford: University, 2015.

GUBA, E.; LINCOLN, Y. Competing paradigms in qualitative research. In: DENZIN, N.; LINCOLN, Y. (Ed.). Handbook of qualitative research. Thousand Oaks: Sage, 1994. p. $105-117$.

KEKI. Establishing child-friendly justice: reflections on how to bring the child forward in the future justice policy of the European Union. Ghent: Children's Rights Knowledge Centre, 2013.

LANSDOWN, G. Every child's right to be heard: a resource guide on the UN Committee on the rights of the child general comment no 12. London: Save the Children UK, 2011.

LANSDOWN, G. The realisation of children's participation rights: critical reflections. In: PERCY-SMITH, B.; THOMAS, N. (Ed.). A handbook of children and young people's participation: perspectives from theory and practice. London: Routledge, 2010. p. 11-23.

MANNION, G. Going spatial, going relational: why "listening to children" and children's participation needs reframing. Discourse: Studies in the Cultural Politics of Education, v. 28 , n. 3 , p. $405-420,2007$.

MAYALL, B. Towards a sociology for childhood: thinking from children's lives. Buckingham: Open University, 2002.

MELO, M. F.; SANI, A. A audição da criança na tomada de decisão dos magistrados. Revista de Psicología, Santiago, v. 24, n. 1, p. 1-19, 2015.

PERCY-SMITH, B.; THOMAS, N. (Ed.). A handbook of children and young people's participation: perspectives from theory and practice. Oxon/New York: Routledge, 2010.

QVORTRUP, J.; CORSARO, W.; HONIG, M.-S. The Palgrave handbook of childhood studies. Basingstoke: Palgrave Macmillan, 2009. 
RIBEIRO, C. A criança na justiça: trajectórias e significados do processo judicial de crianças vítimas de abuso sexual intrafamiliar. Coimbra: Almedina, 2009.

SARMENTO, M. J.; FERNANDES, N.; TOMÁS, C. Políticas públicas e participação infantil. Educação, Sociedade e Cultura, Porto, v. 25, p. 183-206, 2007.

STAKE, R. A arte da investigação com estudos de caso. Lisboa: Calouste Gulbenkian, 2009.

TREVISAN, G. "Somos as pessoas que temos de escolher, não são as outras pessoas que escolhem por nós". Infância e cenários de participação pública: uma análise sociológica dos modos de codecisão das crianças na escola e na cidade. 2014. $524 \mathrm{f}$. Tese (Doutoramento em Estudos da Criança) - Programa de Pós-Graduação em Estudos da Criança, Universidade do Minho, Braga, 2014.

VERHELLEN, E. The Convention on the Rights of the Child: reflections from a historical, social policy and educational perspective. In: VANDENHOLE, W. et al. (Ed.) Routledge international handbook of children's rights studies. London/New York: Routledge, 2015. p. 43-59.

WYNESS, M. Childhood. Cambridge: Polity, 2015.

YIN, R. Estudo de caso: planejamento e métodos. 2. ed. Porto Alegre: Bookman, 2001.

\section{Helga Cláudia Castro (Portugal, Braga) \\ Universidade do Minho (UM)}

Jurist, Master in Social Work and PhD in Child Studies, with specialization in Child Sociology. Scientific works developed favored qualitative approaches and focused especially on the dialectic between legislation and professional practices, the deepening of the understanding of the promotion and protection model, as well as the effective and affective applicability of children's rights. Training and supervision in the areas of protection of children at risk, domestic violence, gender equality, children's rights and residential care. Participation in scientific events, national and international, covering the areas of interest, as well as the presentation of research work.

E-mail: helgacastro@sapo.pt. 


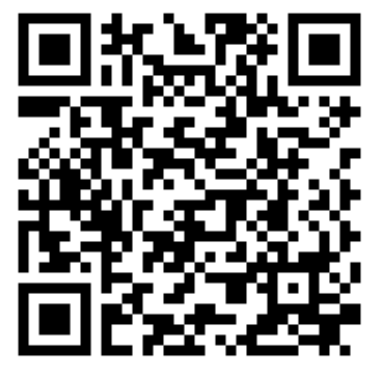

Received on September 27, 2019.

Accepted on October 21, 2019. 